\title{
Efficacy of Natural Wetlands along Wadi Zomer as a Sustainable Phytoremediation Alternative for Industrial Effluents from Nablus West, Palestine
}

Odai A. Attili ${ }^{1}$, Rashed M. Al-Sa ${ }^{\prime}{ }^{2},{ }^{*} \underline{I D}$

${ }^{1}$ Agricultural Development Association (PARC), Tulkarm, Palestine; odai-attili@hotmail.com (O.A.A.)

${ }^{2}$ Institute of Environmental and Water Studies (IEWS), Birzeit University (BZU), Birzeit, PO Box 14, Palestine

* Correspondence: rsaed@birzeit.edu (R.M.A.); M: +972-599 999820

\begin{abstract}
This paper investigated the effectiveness of natural wetlands (Phragmites australis) along Wadi Zomer in reducing the organic and inorganic pollution loads from diverse industrial discharges including occasional emergency discharges from Nablus West Sewage Treatment Plant (NWSTP), Palestine. We monitored physical and chemical parameters at four selective sampling stations (S1-S4) along Wadi Zomer with a length of $5 \mathrm{~km}$ downstream of NWSTP to assess the purification capacity of Wadi Zomer treatment wetlands (water, sediment and vegetation) with Phragmites australis in pollution loads reduction. The results showed that S2 $(0+0.5 \mathrm{~km})$ and S3 $(0+3.0 \mathrm{~km})$ reflected an increase in pollution loads due to illicit industrial discharge and sewer overflow discharge form NWSTP during emergency conditions. BOD values varied significantly along the sampling sites from $6.64 \mathrm{mg} / \mathrm{l}(\mathrm{S} 1)$ to $437.10 \mathrm{mg} / \mathrm{l}(\mathrm{S} 3)$. The BOD at S1 and S2 in water samples were below the Palestinian Water Standard (PWS) compared to S3 and S4 with 437.1 and $333.9 \mathrm{mg} / 1$, respectively. Water samples from all sites (S1-S4) showed a decreasing tendency in heavy metals concentrations $(\mathrm{Fe}>\mathrm{Cu}>\mathrm{Zn}>\mathrm{Cr}>\mathrm{Ni}$ ) and were below the PWS limits, sediment samples followed the same decrease pattern for $\mathrm{Zn}, \mathrm{Cr}$ and $\mathrm{Ni}$ content with Wadi Zomer flow course. The concentration of Fe $(6687 \mathrm{mg} / \mathrm{kg})$ and $\mathrm{Cu}(1384.7 \mathrm{mg} / \mathrm{kg})$ were highest in the sediment samples (S1-S4); this might be due to non-point sources of pollution. The research demonstrated that phytoremediation, is a sustainable nature-based technology for the restoration of heavily polluted surface water bodies in Palestine.
\end{abstract}

Keywords: Heavy metals; industrial wastewater; natural wetlands; phytoremediation; Wadi Zomer restoration; water quality. 


\section{Introduction}

Water is one of the most important resources for all living things. Water is not only an essential element for agricultural food security, but plays a key role in the industry, agriculture, tourism and environmental conservation. The Israeli-Palestinian water conflict further aggravates an environment already characterized by water scarcity [1]. Water scarcity is raising the alarm in achieving sustainable development progress [2]. Increased human activities and using streams and rivers at large-scale resulted in poor water quality and ecosystem degradation [3]. The components of industrial wastewater differ from the municipal wastewater by the content of organic matter and nutrients [4]. Industrial wastewater is less biodegradable compared to other kinds of wastewater and also contains hazardous substances, thus having an negative effect on ecological service, economic and social development [5]. Industrial wastewater without prior pretreatment discharged directly into receiving watershed could result in pollution and harm human health and the environment system. Heavy metals produced from industrial wastewater can negatively affect soil, water quality and human health. It can lastly enter the human body through food chains. Heavy metals are characterized by toxic properties even at low concentrations [6-9]. Groundwater pollution occurs through chemicals present in wastewater where watersheds are at risk due to the increase in chemical accumulation and this pollution continues for long periods even after it stops from the main source [10]. Thus, to avoid the occurrence of accumulation in the human body or groundwater, wastewater treatment could be accomplished by chemical, physical and phytoremediation methods [11]. Phytoremediation is a multi-service treatment method for treating contaminated water and soil by using specific types of plants ([12]. Natural Wetlands (NWs) and constructed wetlands (CWs) describe nature-based treatment processes aiming at the removal of organic and nutrients from municipal wastewater. The use of NWs and CWs is an accepted ecotechnology, especially beneficial to rural areas or industries that cannot afford expensive conventional treatment systems [13]. Both CWs and NWs, established at various scales, are constructed for domestic, industrial, municipal wastewater and leachate. Ever increased and stringent water quality rules and effluent standards urged policymakers to search for ecofriendly natural treatment systems including wetlands $[14,15]$. In Palestine, the water and environmental problems have increased in spatial distribution over the last two decades with improper practices and inadequate management of industrial and municipal wastewater streams. Lack of sustainable management and poor financial resources are responsible for the gross pollution of the receiving 
water bodies, increased water borne diseases, loss of water value and political dispute with regional water agencies. Previous studies [16] reported that five Palestinian Wadis, small streams with seasonal flows, are heavily polluted, but they did not explore the role of nature-based technologies to improve water quality and reduce public health and ecosystem hazards. With an increased understanding of the importance of surface water quality monitoring to public health, groundwater and aquatic life, there is a great need to assess the water quality and understand the role of phytoremediation in major Wadis restoration in Palestine. According to [17], organic and inorganic pollutants of various origins are heavily polluting almost all water bodies in Palestine. Al-Sa`ed [17] has developed a policy framework for receiving water bodies including groundwater, streams and water reservoirs, subject for incidents of industrial pollution loads (organic and inorganic substances). He reported selected case studies, where transboundary watercourses are heavily polluted with illicit industrial discharges. This practice caused political and economic disputes between the Palestinian Authority and Israeli water related agencies. According to Yaqob et al. [18] seventy million cubic meter of wastewater, produced from the West Bank, flow towards the green line. Wadi Zomer is produces almost 6 million cubic meter of wastewater annually, or $35 \%$ of the wastewater that crosses into the green line. Additional waste channels flow into the Wadi along its length from the other sources like stone cutting factories, olive processing plants and runoff from nearby agricultural areas [19]. Abu Ghosh et al. [20] reported that the watershed of Nablus West sewage treatment plant (NWSTP) with increased number of industrial facilities (262) including olive mills (7) and stone cutting sites (75) could harm treatment processes, if raw industrial effluents are discharged without prior pretreatment.

\section{Materials and methods}

\subsection{Description of study area}

The main channel of Zomer has a total length $44 \mathrm{~km}, 17 \mathrm{~km}$ of which inside the green line Historical Palestine (Tal et al., 2010). The Palestinian part of the Wadi spans over $27 \mathrm{~km}$ from Nablus city to Tulkarm city [19]. This study covers $5 \mathrm{~km}$ in middle of the overall distance Palestinian part (Figure 1). The average temperature ranges between $8^{\circ} \mathrm{C}$ to $14^{\circ} \mathrm{C}$ in winter and $21.9^{\circ} \mathrm{C}$ to $40^{\circ} \mathrm{C}$ in summer; the average relative humidity varies from 39 percent in May to 84 percent in January. Humidity is at its highest in the early morning and lowest in the early afternoon [21. NWSTP, since its establishment in 2013, around 5.3 MCM of treated water, as water for 
nature, drained into Wadi Zomer in 2019. However, frequent illicit industrial discharges and uncontrolled septage disposal form a challenge, and call for urgent actions [20].

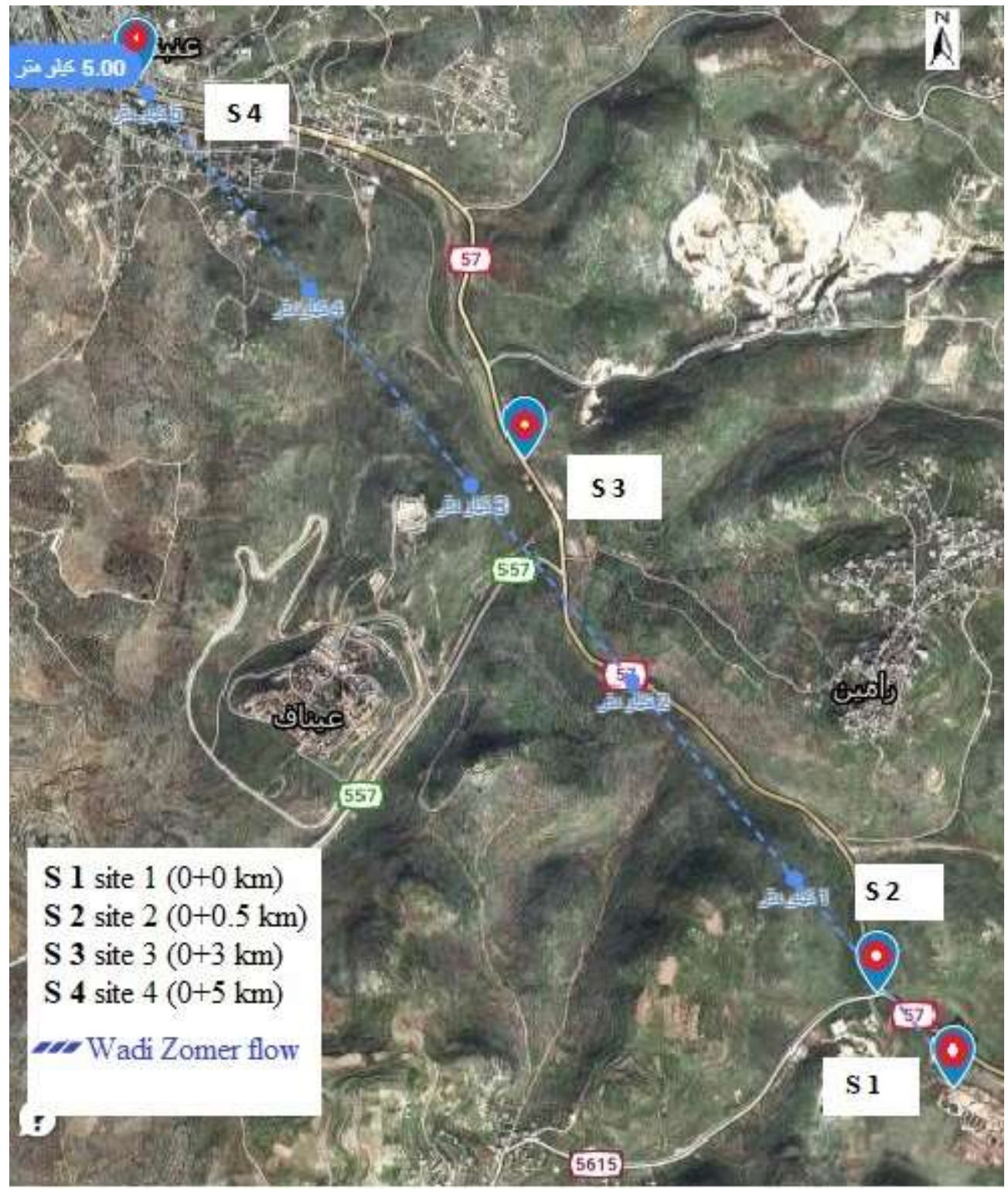

Figure 1. Study area and sampling sites along Wadi Zomer (not to scale)

\subsection{Experimental setup and sampling methodology}

Samples were collected for a period of eight months (August to December 2019, and January to March 2020) through the flowing water in the Wadi. Four sampling stations were identified considering the diverse environmental flows in Wadi Zomer (Fig. 1). Sampling station S1 $(0+0.0$ $\mathrm{km}$ ) represents the first site for water sampling, the outlet of Nablus West sewage treatment plant 
(NWSTP). This the main tributary as baseline environmental flow, which meets incidental sewer overflows form NWSTP headworks, illicit industrial discharges and septage disposal into Wadi Zomer. Station S2, located about 500 meters $(0+0.5 \mathrm{~km})$ far from S1, is the bridge near the main entrance to Beit Leed town. Here it is worth noting that the treated water from NWSTP is further mixed with domestic sewage from Beit Leed town. Station S3 $(0+3.0 \mathrm{~km})$, represents a water flow section without additional industrial activities or domestic sewage discharge into the Wadi but there could be drainage from the settlement near the third site. The final station $\mathrm{S} 4(0+5.0 \mathrm{~km})$ receives mixed pollution loads from households and agri-food industries in the middle town of Anabta and some nearby village.

\subsection{Analysis of Water, Sediment, and Vegetation Samples}

Four water parameters were measured using field instruments (in situ), WTW (Germany) Inolab $\mathrm{pH} /$ Oximeter for the Wadi, in the four sampling stations, these parameters included $\mathrm{pH}$, temperature (T), Dissolved oxygen (DO), electric conductivity (EC). Directly after sampling, water and sediment from Wadi Zomer were subjected to analysis following standard methods [22]. Major parameters Total suspended solid (TSS), Total Phosphorus (TP), Biochemical Oxygen Demand (BOD5), Chemical Oxygen Demand (COD), ammonium $\left(\mathrm{NH}_{4}-\mathrm{N}\right)$ and nitrate $\left(\mathrm{NO}_{3}-\mathrm{N}\right)$ in water and sediment in accordance with the standard methods [22] and then analyzed by Atomic Emission Spectrophotometer (ICP-AES). Vegetation samples from leaves, stem and roots were analyzed for the detection of selective heavy metals ( $\mathrm{Zn}, \mathrm{Fe}, \mathrm{Mn}, \mathrm{Cu}, \mathrm{Ni}, \mathrm{Pb}, \mathrm{Cr}$ ). One gram of dry weight of each sample was digested using the following digestion mixture (Conc. $\mathrm{HNO}_{3}$, $\left.\mathrm{H}_{2} \mathrm{SO}_{4}, \mathrm{H}_{2} \mathrm{O}_{2}\right)$ in the ratio (1:3:3). The heavy metal concentration in plant parts (leaves stem and roots) were measured using ICP-AES and the results are expressed in $\mathrm{mg} / \mathrm{kg}$ [23] as dry weight.

\subsection{Statistical analysis}

The MS Excel and Graphpad prism version 8 software, for Windows version 10, was used to analyze the obtained results data. The mean and standard errors were used to assess the data accuracy. The mean of parameters $( \pm \mathrm{SE})$ and one-way analysis of variance (ANOVA) was performed with the SPSS version 26 software package followed by a post hoc multiple comparison (Tukey's test) were calculated to compare the mean values of observation based on the sites under investigation. The differences in mean values obtained were considered significant if calculated P- 
values were less than 0.05 . The correlation analysis was done to test the association between different parameters along testing sites along the Wadi Zomer.

\section{Results and Discussions}

\subsection{Wadi Zomer flow characterization}

Physicochemical analysis of flow water samples in the studied four sites along the Wadi Zomer represented in (Table 1). The $\mathrm{pH}$ value was considered normal and it was within the normal range, the $\mathrm{pH}$ values showed insignificant variations along the sampling sites and ranged between $7.23 \pm 0.04$ and 7.61 \pm 0.05 . Bello et al. [24] reported that the $P$. australis preferred an acidic to neutral condition for both cadmium and lead remediation, but a $\mathrm{pH}$ performed better at $\mathrm{pH} 10$ for nickel remediation. He showed that also the temperature in all sites were normal between 20.2-22 $\mathrm{C}^{\circ}$, except in the first site it was below than the average normal range. Probably is that the first site inside NWSTP in the final assembly area (outlet) before discharge into the Zomer stream, often covered from the sunlight. Temperature influences the solubility and, thus, the availability of oxygen in water [24].

Table 1. Mean \pm SD for parameter measured in water samples at all sites*) $(n=11)$

\begin{tabular}{|c|c|c|c|c|c|}
\hline Parameter & $\begin{array}{c}\text { Site 1 } \\
\mathbf{( 0 + 0 . 0} \mathbf{~ k m})\end{array}$ & $\begin{array}{c}\text { Site 2 } \\
\mathbf{( 0 + 0 . 5} \mathbf{~ k m})\end{array}$ & $\begin{array}{c}\text { Site 3 } \\
\mathbf{( 0 + 3 . 0} \mathbf{~ k m})\end{array}$ & $\begin{array}{c}\text { Site 4 } \\
\mathbf{( 0 + 5 . 0} \mathbf{~ k m})\end{array}$ & $\begin{array}{c}\text { PVL227 } \\
\mathbf{( P S I , ~} \\
\mathbf{2 0 1 0})\end{array}$ \\
\hline $\mathbf{p H}$ & $7.61 \pm 0.05$ & $7.4 \pm 0.05$ & $7.23 \pm .0 .05$ & $7.24 \pm 0.05$ & $6-9$ \\
\hline T & $20.9 \pm 0.7$ & $21.2 \pm 0.7$ & $21.3 \pm 0.7$ & $21.4 \pm 0.7$ & - \\
\hline DO & $0.02 \pm .0 .01$ & $1.3 \pm .0 .12$ & $2.1 \pm 0.19$ & $3.3 \pm 0.23$ & $<2$ \\
\hline TSS & $5.6 \pm 0.9$ & $109.1 \pm 14.5$ & $102.5 \pm 9.7$ & $81.1 \pm 5.5$ & 60 \\
\hline NH4_N & $8.2 \pm 1.02$ & $28.1 \pm 1.95$ & $21.3 \pm 1.97$ & $16.5 \pm 1.07$ & 5 \\
\hline NO__N & $0.24 \pm 0.06$ & $0.13 \pm 0.01$ & $0.19 \pm 0.01$ & $0.49 \pm 0.02$ & 50 \\
\hline Total-P & $4.9 \pm 0.2$ & $6.2 \pm 0.3$ & $5.6 \pm 0.3$ & $6.3 \pm 0.2$ & $15-20$ \\
\hline EC ( $\boldsymbol{\mu S} / \mathbf{c m})$ & $1407.3 \pm 26.8$ & $1595.3 \pm 27.4$ & $1508.6 \pm 21.7$ & $1508.7 \pm 33.2$ & - \\
\hline COD & $24.8 \pm 3.6$ & $122.2 \pm 24.2$ & $899.7 \pm 605.9$ & $708.1 \pm 511.1$ & 150 \\
\hline BOD & $6.6 \pm 0.7$ & $57.6 \pm 11.4$ & $437.1 \pm 300.8$ & $333.9 \pm 233.7$ & 60 \\
\hline
\end{tabular}

PLV: Palestinian values limit (PSI, 2010) ${ }^{*}$ All units are in $\mathrm{mg} / \mathrm{l}$, otherwise stated. 
Concerning DO content, the lowest value for DO was measured in site 1, while the highest value was recorded in site 4. According to the established criteria, the range must be below than $2 \mathrm{mg}$ $\mathrm{O}_{2} / 1$. This may be due to topographical distribution of monitoring stations and the time of sampling, and may change with season. When studying the water quality of flowing rivers, Matamoros and Rodríguez [26] recorded a dissolved oxygen rise in the direction of the downstream flow. In surface water bodies that receive partially treated wastewater, Edokpayi et al. [10] reported a significant and increasing depletion of the DO. Regarding the EC, site 2 (main entrance to Beit Leed town) showed the highest EC values. This might be due to the presence of metal salts $(\mathrm{Na}+$, $\mathrm{Ca}^{2+}, \mathrm{Mg}^{2+}, \mathrm{K}^{+}, \mathrm{Cl}^{-}, \mathrm{SO}_{4}^{-2}$ and $\mathrm{HCO}_{3}{ }^{-}$) leading to higher EC values [27, 28].

The TSS varied significantly and ranged from $5.6 \pm 0.9 \mathrm{mg} / 1$ to $109.1 \pm 14.5 \mathrm{mg} / 1$ (Figure 2). TSS level were generally above the PVL 227 standards [29] permissible limits (60 mg/l) except site 1. A promising result were shown between TSS and temperature, TSS and dissolved oxygen, since as shown in Table 1.

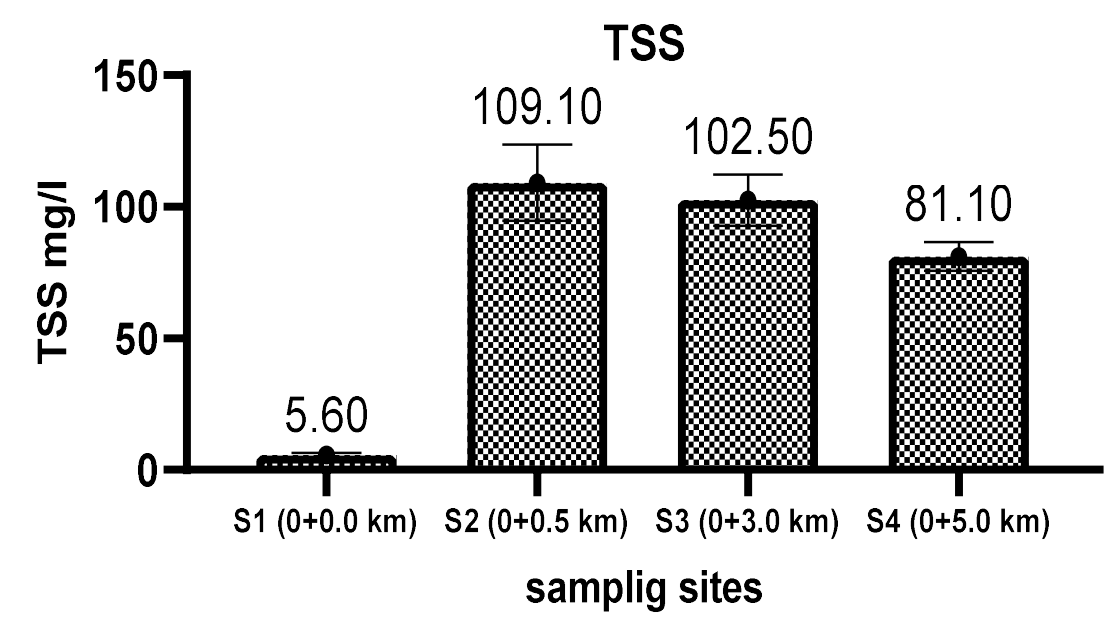

Figure 2. Total suspended solid (TSS) in water samples at various sites of Wadi Zomer.

Ammonium-N was found at higher levels in all site exceeding the limits of PVL 227 [29] of $5 \mathrm{mg} / 1$ (Table 1). The lowest value of Ammonium was recorded at site 1 and the highest value in site 2. NO3-N was reduced in all site below the limits of PVL 227 [29], which was $50 \mathrm{mg} / 1$. Ammonium, and nitrate concentrations significantly changed along the length of the Zomer stream (Figure 3). 
$\mathrm{TP}$ in all site were considered normal and ranged from 4.9-6.2 mg/l. TP levels were generally below the PVL 227 (PSI, 2010) permissible limits (15 mg/l) at all sampling sites.

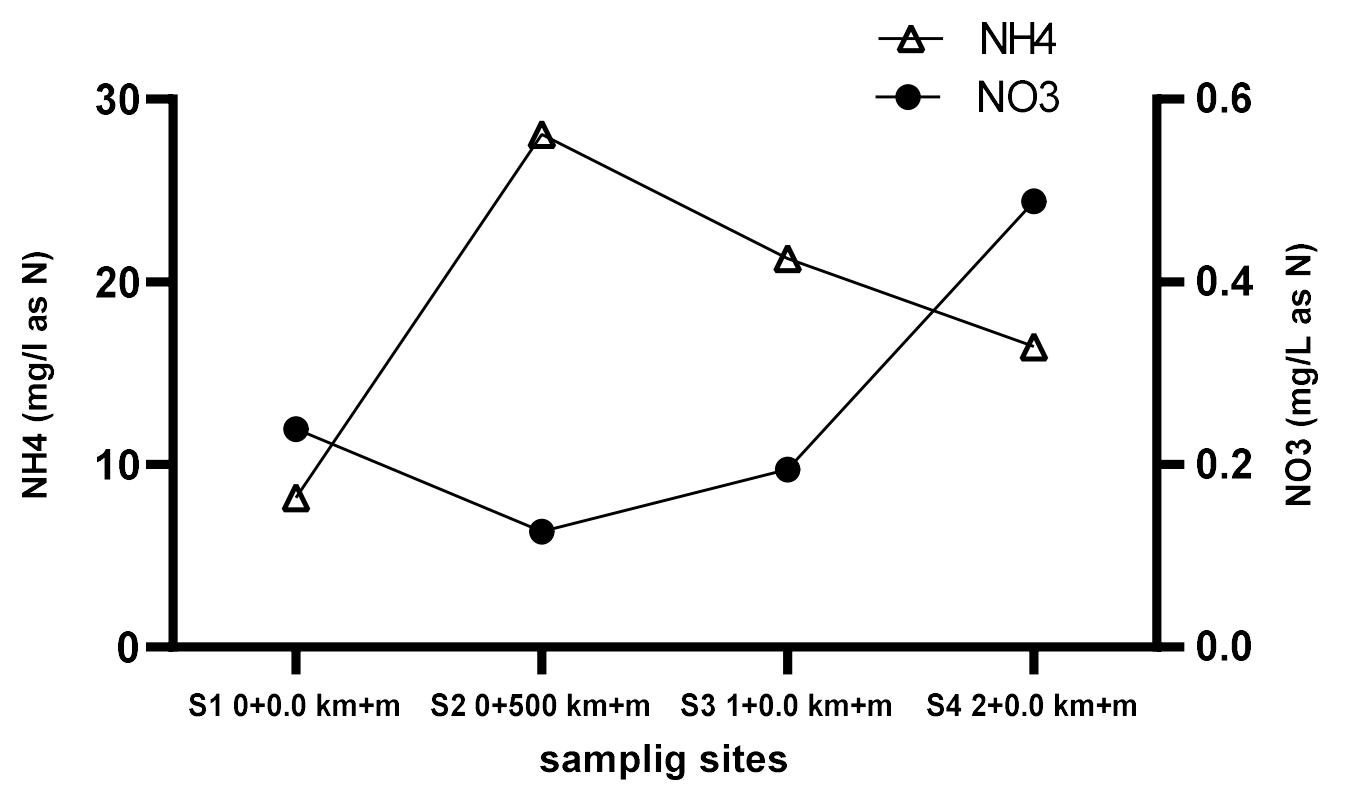

Figure 3. Concentration of ammonium and nitrate at various sites along Wadi Zomer.

BOD varied significantly along sampling sites and ranged from 6.6 to $333.9 \mathrm{mg} / \mathrm{l}$. The study revealed that the water in site 1 and site 2 had BOD levels below PVL 227 (PSI, 2010) and that site 3 and site 4 had BOD levels 437.1, $333.9 \mathrm{mg} / \mathrm{l}$ respectively, above the maximum permissible limits given by the PVL 227. COD varied significantly along sampling and ranged from 24.8 to $899.7 \mathrm{mg} / 1$. The study revealed that the water in site 1 and site 2 had COD levels below PVL 227

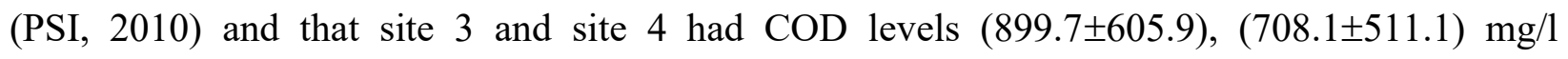
respectively, above the maximum permissible limits given by the PVL 227. Low levels of BOD and COD in rivers indicate improvement in water quality, where high pollution levels may cause degradation in ecosystem health and fuel a regional political conflict.

\subsection{Heavy metals content in water samples at four sampling sites}

The results obtained from analysis of wastewater samples along the five kilometer of Wadi Zomer are summarized in (Table 2). The heavy metals analyzed are $\mathrm{Zn}, \mathrm{Fe}, \mathrm{Cu}, \mathrm{Pb}, \mathrm{Ni}$, and $\mathrm{Cr}$. The concentration of the heavy metals was in the flowing waters of the Wadi within the permissible limits PVL227 (PSI, 2010). Except the Cr in the site 2. High levels of Nickle exceeding PVL limits 
were recorded at site 2 and site 3. Dheri et al. [30] found that the high concentration of Cr was due to the discharge of untreated industrial water.

Table 2. Mean \pm SD for heavy metals measured in water samples at all sites*) $(n=11)$

\begin{tabular}{|c|c|c|c|c|c|}
\hline Parameter & $\begin{array}{c}\text { Site 1 } \\
\mathbf{( 0 + 0 . 0} \mathbf{~ k m})\end{array}$ & $\begin{array}{c}\text { Site 2 } \\
\mathbf{( 0 + 0 . 5} \mathbf{~ k m})\end{array}$ & $\begin{array}{c}\text { Site 3 } \\
\mathbf{( 0 + 3 . 0} \mathbf{~ k m})\end{array}$ & $\begin{array}{c}\text { Site 4 } \\
\mathbf{( 0 + 5 . 0} \mathbf{~ k m})\end{array}$ & $\begin{array}{c}\text { PVL227 } \\
\text { PSI [29] }\end{array}$ \\
\hline $\mathbf{Z n}$ & $0.9 \pm 0.8$ & $0.2 \pm 0.04$ & $0.3 \pm .0 .03$ & $0.12 \pm 0.02$ & 2 \\
\hline $\mathbf{F e}$ & $0.2 \pm 0.1$ & $1.8 \pm 0.2$ & $4 \pm 0.6$ & $1.6 \pm 0.2$ & 5 \\
\hline $\mathbf{C u}$ & $0.14 \pm 0.002$ & $0.12 \pm 0.002$ & $0.1 \pm 0.004$ & $0.07 \pm 0.005$ & 0.2 \\
\hline $\mathbf{P b}$ & $0.15 \pm 0.005$ & $0.06 \pm 0.01$ & $0.06 \pm 0.01$ & $0.04 \pm 0.005$ & 0.2 \\
\hline $\mathbf{N i}$ & $0.2 \pm 0.009$ & $0.3 \pm 0.01$ & $0.3 \pm 0.02$ & $0.1 \pm 0.01$ & 0.2 \\
\hline $\mathbf{C r}$ & $0.14 \pm 0.005$ & $0.22 \pm 0.01$ & $0.08 \pm 0.02$ & $0.04 \pm 0.01$ & 0.1 \\
\hline
\end{tabular}

PLV: Palestinian values limit according to PSI [29]

${ }^{*}$ All units are in $\mathrm{mg} / \mathrm{l}$

\subsection{Heavy metals in stream sediment from all sampling sites}

The results in Table 3 depicts the highest value was found in the sediment for Fe was $6687 \mathrm{mg} / \mathrm{kg}$ and the lowest value $10.5 \mathrm{mg} / \mathrm{kg}$ for $\mathrm{Ni}$. The concentration of $\mathrm{Zn}, \mathrm{Cu}$ and $\mathrm{Cr}$ were at levels of 293.1 $\mathrm{mg} / \mathrm{kg}, 1384.7 \mathrm{mg} / \mathrm{kg}$, and $52.7 \mathrm{mg} / \mathrm{kg}$, respectively. Heavy metals in stream sediments was found to increase in order of $\mathrm{Fe}>\mathrm{Cu} \mathrm{Zn}>\mathrm{Cr}>\mathrm{Ni}$.

Table 3. Concentrations of heavy metals in sediment* $(n=3)$

\begin{tabular}{|c|c|c|c|c|c|c|}
\hline Metals & Zn & Fe & Cu & Pb & Ni & Cr \\
\hline Sediment & 293.13 & 6687 & 1384.77 & BDL & 10.53 & 52.77 \\
\hline Control & 21.16 & 16.81 & 8.99 & 3.60 & 16.92 & 25.05 \\
\hline
\end{tabular}

* All units are in $\mathrm{mg} / \mathrm{Kg}$

BDL: below the detection limit

Anthropogenic activities have a negative impact on the environment, because they can release a diversity of pollutants including heavy metals through point sources. Manmade activities reflected in industrial and agri-food industrial activities could release heavy metals in wastewater causing heavy metals pollution in rivers from non-point sources [31, 32]. The heavy metals can be considered as the results of industrial and from the outputs of agricultural manufacturing. A recent study by Khan et al. [33] showed that $\mathrm{Cr}$ in the sediment sample was ( $70 \mathrm{mg} / \mathrm{kg}$ ) compared to our 
result that was $(52.7 \mathrm{mg} / \mathrm{kg})$ and Zinc is found $780 \mathrm{mg} / \mathrm{kg}$ compared to our result that was 293.1 $\mathrm{mg} / \mathrm{kg}$. In our study, Fe recorded high concentration in sediment samples (6687 $\mathrm{mg} / \mathrm{kg})$, close to reported data in sediments of SUEZ GULF (7497 mg/kg) [34]. Table (4) shows our obtained data on heavy metals contents in sediment samples compared with published literature data.

Table 4. Sediment metals concentrations ( $\mathrm{mg} / \mathrm{kg})$-this study versus literature data

\begin{tabular}{|l|r|r|r|r|r|r|l|}
\hline Site & \multicolumn{1}{|c|}{$\mathbf{C u}$} & \multicolumn{1}{c|}{ Pb } & \multicolumn{1}{c|}{ Zn } & \multicolumn{1}{c|}{ Cr } & \multicolumn{1}{c|}{ Ni } & \multicolumn{1}{l|}{ Fe } & Sources \\
\hline Odiel River & 607 & 2369 & 2874 & 54.7 & 29.7 & 31862 & {$[57$} \\
\hline Haihe River & 28.52 & 25.20 & 84 & 57.55 & 32.71 & 29500 & {$[58]$} \\
\hline Yangtze River & 30.7 & 27.3 & 94 & 78.9 & 31.8 & 33.394 & {$[11]$} \\
\hline Suez Gulf & 33.2 & 70.44 & 159.4 & 32.04 & 71.44 & 7497 & {$[34]$} \\
\hline Our study & 1384.7 & ND & 293.1 & 52.7 & 10.5 & 6687 & This study \\
\hline
\end{tabular}

*) All units are in $\mathrm{mg} / \mathrm{kg}$ dry weight sediment samples; ND: not detected

Copper $(\mathrm{Cu})$, which is regarded as a serious pollutant of aquatic ecosystems, was the second higher in concentration during this study. Nickel is a common pollutant resulting from various industrial activities like production of $\mathrm{Ni}-\mathrm{Cd}$ batteries, waste incineration, and domestic wastewater. $\mathrm{Ni}$ concentrations $(10.5 \mathrm{mg} / \mathrm{kg})$, which indicated a presence of Ni contamination in Wadi Zomer.

\subsection{Heavy metals in vegetation parts of $P$. australis}

The results shown in (Table 5) that the highest value was found in the plant leaves are Fe (326.3 $\mathrm{mg} / \mathrm{kg}$ ) and that the lowest value is for $\mathrm{Ni}(6.7 \mathrm{mg} / \mathrm{kg})$, and the concentrations for $\mathrm{Zn}, \mathrm{Cu}$ and $\mathrm{Cr}$ were at levels of $80.3 \mathrm{mg} / \mathrm{kg}, 12.5 \mathrm{mg} / \mathrm{kg}, 51 \mathrm{mg} / \mathrm{kg}$, respectively, except that the $\mathrm{Pb}$ metals was below the detection limits. Heavy metals in P. Australis (leaves) was found to increase in order of: $\mathrm{Fe}>\mathrm{Zn}>\mathrm{Cr}>\mathrm{Cu}>\mathrm{Ni}$. As shown in Table (5), the highest value was found in the plant stem are $\mathrm{Fe}$ $435.1 \mathrm{mg} / \mathrm{kg}$ and the lowest value for $\mathrm{Cr} 1.6 \mathrm{mg} / \mathrm{kg}$. The content for $\mathrm{Zn}, \mathrm{Cu}, \mathrm{Ni}$, and $\mathrm{Pb}$ were at levels of $73.3 \mathrm{mg} / \mathrm{kg}, 11.9 \mathrm{mg} / \mathrm{kg}, 6.4 \mathrm{mg} / \mathrm{kg}, 4.9 \mathrm{mg} / \mathrm{kg}$, respectively, the metal of $\mathrm{Pb}$ was detected in the leaf, but present in the stems with a concentration of $4.9 \mathrm{mg} / \mathrm{kg}$.

Heavy metals in P. Australis (stem) showed an increase in order of $\mathrm{Fe}>\mathrm{Zn}>\mathrm{Cu}>\mathrm{Ni}>\mathrm{Pb}>\mathrm{Cr}$. The results shown in (Table 5) lists the highest value found in the roots for Fe $21654 \mathrm{mg} / \mathrm{kg}$ and the lowest value for $\mathrm{Pb} 6.6 \mathrm{mg} / \mathrm{kg}$. 
Table 5. Concentrations of heavy metals $(\mathrm{mg} / \mathrm{kg})$ in $P$. australis in three vegetation samples

\begin{tabular}{|c|c|c|c|}
\hline Heavy Metals & Plant leaf & Plant stem & Plant root \\
\hline $\mathbf{Z n}$ & 80.3 & 73.3 & 127 \\
\hline $\mathbf{F e}$ & 326.3 & 435.1 & 21654 \\
\hline $\mathbf{C u}$ & 12.5 & 11.9 & 30.3 \\
\hline $\mathbf{P b}$ & BDL & 4.9 & 6.6 \\
\hline $\mathbf{N i}$ & 6.7 & 6.4 & 22.4 \\
\hline $\mathbf{C r}$ & 51 & 1.6 & 24.4 \\
\hline
\end{tabular}

BDL: below the detection limit

The concentration of $\mathrm{Zn}, \mathrm{Cu}, \mathrm{Cr}$ and $\mathrm{Ni}$ in the roots were recorded as $127 \mathrm{mg} / \mathrm{kg}, 30.3 \mathrm{mg} / \mathrm{kg}, 22.4$ $\mathrm{mg} / \mathrm{kg}$, respectively. Heavy metals in P. Australis (roots) was found to increase in order of Fe> $\mathrm{Zn}>\mathrm{Cu}>\mathrm{Cr}>\mathrm{Ni}>\mathrm{Pb}$. Recent review [35] on the importance of biological and ecological properties of $P$. Australis found that metal uptake through phytoremediation can be affected by soil $\mathrm{pH}$, cation capacity, clay substance, organic matter substance and the presence of other ions. P. australis are for the most part impacted more by metals in sediment than by those ones in water, subsequently, bioaccumulation is more noteworthy when sediments are contaminated. We found the highest concentration in root except for chrome. The highest concentrations for Fe and $\mathrm{Zn}$ were found in the roots. Moreover, the concentration of trace metals was high in the roots than in the aerial parts [36]. Our results revealed that heavy metals are accumulated more in the roots, which complies with published data on gradual accumulation of trace metals in the roots of $P$. australis during the seasonal cycle [37, 38]. All plant organ displayed strong abilities to accumulate heavy metals in their roots and stems whereas large accumulation was found in the roots. Previous studies [39, 40] reported that roots showed higher affinity to towards heavy metals ( $\mathrm{Zn}$ and $\mathrm{Cu}$ ) accumulation than stem and leaves, thus roots could act as barrier against heavy metals transfer from sediment. In our research, the roots showed a high accumulation of heavy metals, which is due to sediment. According to Sawidis et al. [41], roots of P. australis can accumulate awesome amount of overwhelming metals because of the cortex parenchyma with intercellular air spaces. Fe in all plants organ was translocated from roots to stems, but the accumulation of roots remained higher. By contrast, results with high translocation of Fe in the shoot have also been previously reported but in different plant types [42]. Zn plays an important role in the environment and can revitalize the most prominent role in plant nutrition and enzymatic activities. The concentration value that 
detected in stems and leaves were in agreement with various authors [43]. Zn concentrations in all plant organs were significantly below the phytotoxic range of 500-1500 mg/kg [44]. Search results showed zinc concentration was around $70.2 \mathrm{mg} / \mathrm{kg}$ compared to our research results $80.3 \mathrm{mg} / \mathrm{kg}$ that use Phragmites australis for land fill leach at treatment [45]. Research results published by Windham et al. [43] revealed that the concentration of zinc in the leaf reached $79.03 \mathrm{mg} / \mathrm{kg}$ compared to the search result that we recorded $80.3 \mathrm{mg} / \mathrm{kg}$. Cu plays a vital role in plant sustenance at low concentrations but becomes harmful at higher levels [46]. However, $\mathrm{Cu}$ concentrations in all plant were below the phytotoxic range of $25-40 \mathrm{mg} / \mathrm{kg}$ [44]. In their study, Yeh et al. [47] studies the uptake leaf for copper element (12 mg/kg) using constructed wetlands treating river contaminated water by confined swine operations, the findings are close to our recorded data for $\mathrm{Cu}(12.5 \mathrm{mg} / \mathrm{kg})$. Swedish examination uncovered that copper and zinc were taken by plants with the most noteworthy aggregation found within the roots (48). $\mathrm{Pb}$ is immobile in soil and tends to accumulate in roots [49]. $\mathrm{Pb}$ concentrations found in this study were higher than values reported by various author, especially as regards to stem [50]. $\mathrm{Pb}$ leaf concentrations were below the detection limit of the analytical instrument used. Danube Delta, Romania in 1993 and 1994 investigated patterns of spatial variability in trace metal concentrations in tissues of Phragmites australis, they found $\mathrm{Pb}$ in leaf were $0.2 \mathrm{mg} / \mathrm{kg}$ [51]. Compared to the results of our study that was below detection limit, the highest value was for the presence of lead in plant leaves 31-50 $\mathrm{mg} / \mathrm{kg}$ with a purification and removal rate of $64-81 \%$ [52]. Ni is toxic effects on plants. The values of bioaccumulation in the plant organs agree with Laing et al., [53]. Nickle concentrations in leaf of (Phragmites australis) in the Scheldt estuary was $0.5-5.8 \mathrm{mg} / \mathrm{kg}$ and the differences between our studies might be related to pollution levels and physic-chemical sediment, water or sediments characteristics at the sampling sites [53]. In Belgium, using CWs for domestic wastewater treatment, metal concentrations in the stems for Nickle reached $0.52 \mathrm{mg} / \mathrm{kg}$ compared with our result was $6.4 \mathrm{mg} / \mathrm{kg}$. Concerning chrome, our result revealed $1.6 \mathrm{mg} / \mathrm{kg}$ compared the $1.3 \mathrm{mg} / \mathrm{kg}$ published data [54]. The plant organs in this study showed toxic levels of chrome, Cr is a toxic for plants. According to Allen [55], Cr concentrations greater than $0.5 \mathrm{mg} / \mathrm{kg}$ are toxic to plants. In this study, all of plant organ parts showed $\mathrm{Cr}$ values above the phytotoxic threshold. $\mathrm{Cr}$ concentrations in roots were comparable with data found in other studies showed the concentrations of aerial parts and rhizomes are in agreement with Vymazal and Březinová [56]. A study of patterns of accumulation in the parts of the plant of heavy elements was the result of the 
accumulation of $\mathrm{Zn}$ in the stems $26.6 \mathrm{mg} / \mathrm{kg}$ as the lowest value and the highest value was 75.3 $\mathrm{mg} / \mathrm{kg}$. The result was close to the research result that we reached $73.3 \mathrm{mg} / \mathrm{kg}$, and when compared the result of copper with our result $11.9 \mathrm{mg} / \mathrm{kg}$ we can show the lowest value $1.6 \mathrm{mg} / \mathrm{kg}$ and the highest $19.2 \mathrm{mg} / \mathrm{kg}[43]$.

\section{Conclusions}

The primary objective of this study was to investigate the efficacy of phytoremediation using natural wetlands in Nablus West watershed to improve the water quality along Wadi Zomer flow course. as a index of its capacity to remove selected pollutants from the water flow Along a length of $5 \mathrm{~km}$ downstream of NWSTP. According to the findings of this study, the industrial wastewater that is discharged to the wastewater treatment plant or illegally leaked into Wadi Zomer contains many organic and inorganic pollutants and a rise in the percentage of heavy metals. As it was the highest percentage of heavy metals was iron in all parts of the study. The occasional uncontrolled illicit industrial discharges along the Wadi course and the occasional sewer overflows under emergency events at NWSTP have impaired the water quality at Station S2 $(0+0.5 \mathrm{~km})$ and Station S4 $(0+2.0 \mathrm{~km})$. The shock pollution loads did not affect the efficacy of the self-purification capacity of the natural wetlands, the latter are non-motile and got adapted to pollution. Therefore, the natural wetlands proved an efficient role in phytoextraction of selective heavy metals, thus improved the water quality of Wadi Zomer. Environmental safety and public health call for longterm monitoring of industrial effluents before discharge into public sewers and future studies addressing the long-term impacts on the fate of heavy metals in soil and vegetation along Wadi Zomer, in addition, enforce effective water quality monitoring on industrial and sewage works outlets along Wadi Zomer. Water quality monitoring should include emergent chemicals and bioindicators pertaining to water-borne disease including viruses.

Funding: The Palestinian-Dutch Academic Cooperation (PADUCO2) Program on Water funded this research within the project "Promotion of Applied Integrated Practices and Technologies for Sustainable Industrial Wastewater Management in Palestine (INWA)". Special thanks are due to Tareq Aqhash of Birzeit University Testing Laboratory Center for providing fieldwork and partial lab analysis, especially during the lockdowns due to COVID-19 pandemic.

Conflicts of Interest: The authors declare no conflict of interest. 


\section{References}

1. Abramson, A.; Tal. A.: Becker, N.; El-Khateeb, N.; Asaf, L.; Assi, A.; Adar, E. Stream restoration as a basis for Israeli-Palestinian cooperation: a comparative analysis of two transboundary streams. Int. J. River Basin Manag. 2010, 8(1), 39-53.

2. Rosegrant, M.W. Global outlook for water scarcity, food security, and hydropower. K. Burnett, R. Howitt, J.A. Roumasset, C.A. Wada, (eds); Handbook of Water Economics and Institutions. New York: Routledge, 2015.

3. Vörösmarty, C.J.; Mcintyre, P.B.; Gessner, M.O.; Dudgeon, D.; Prusevich, A.; Green, P.; Davies, P.M. Global threats to human water security and river biodiversity. Nature, 2010, 467(7315), 555-561.

4. Vymazal J. Constructed wetlands for treatment of industrial wastewaters: A review. Ecol. Eng. 2014, 73, 724-751.

5. Li, W.; Hua, T.; Zhou, Q.; Zhang, S.; Rong, W. Toxicity Identification and High-Efficiency Treatment of Aging Chemical Industrial Wastewater from the Hangu Reservoir, China. $J$. Environ. Qual. 2011, 40(6), 1714-1721.

6. Wang, Q.; Yang, Z. Industrial water pollution, water environment treatment, and health risks in China. Environ. Pollut. 2016, 218, 358-365.

7. Azad, A.K.; Ahmed, J.; Alum, M.A.; Hasan, M.M.; Ishikawa, T.; Sawa, Y. Prediction of arsenic and antimony transporter major intrinsic proteins from the genomes of crop plants. Int. J. Biol. Macromol. 2018, 107, 2630-2642.

8. Largo, K.M.; Depablos, J.L.; Espitia-Sarmiento, E.F.; Moreta, N.M. Artificial Floating Island with Vetiver for treatment of arsenic-contaminated water: A real scale study in high-Andean Reservoir. Water 2020, 12, 3086; doi:10.3390/w12113086.

9. Ahmad J.U.; Goni. M.A. Heavy metal contamination in water, soil, and vegetables of the industrial areas in Dhaka, Bangladesh. Environ. Monit. Assess. 2009, 166(1-4), 347-57.

10. Edokpayi, J.N.; Odiyo, J.O.; Durowoju, O.S. Impact of wastewater on surface water quality in developing countries: A case study of South Africa. In Water Quality 2017, DOI: $10.5772 / 66561$.

11. Huang, X.; Zhao, F.; Yu, G.; Song, C.; Geng, Z.; Zhuang, P. Removal of Cu, Zn, Pb, and Cr from Yangtze Estuary using the Phragmites australis artificial floating Wetlands. BioMed Res. Int. 2017, 1-10. 
12. Sarma, H., Metal Hyperaccumulation in Plants: A review focusing on phytoremediation technology. J. Environ. Sci. Technol. 2011, 4(2), 118-138.

13. Wu, C.; Kao, C.; Chen, K.; Sung, W.; Lin, C. Applying natural treatment systems for the improvement of the quality of river water. Proc. 5th International Conference on Responsive Manufacturing - Green Manufacturing, 2010.

14. Zhang, D.Q.; Jinadasa, K.; Gersberg, R.M.; Liu, Y.; Ng, W.J.; Tan, S.K. Application of constructed wetlands for wastewater treatment in developing countries - A review of recent developments (2000-2013). J. Environ. Manag. 2014, 141, 116-131.

15. Suhad A.A.; Almuktar, A.N.; Abed, S. N.; Scholz, M. Wetlands for wastewater treatment and subsequent recycling of treated effluent: A review. Environ. Sci. Pollut. Res. 2018, 25(24), 23595-23623.

16. Samhan, S.; Kurt, F.; Marwan, G.; Wasim, A.; Ayman, J. Domestic water quality in the West Bank aquifers, Palestine: Overview on the major parameters. Proc. $2^{\text {nd }}$ International Conference on Water Values and Rights, pp 620-628, 2010.

17. Al-Sa 'ed, R. A policy framework for trans - boundary wastewater issues along the Green Line, the Israeli-Palestinian border. Int. J. Environ. Stud. 2010, 67(6), 937-954.

18. Yaqob, E.; Al-Sa`ed, R.; Sorial, G.; Suidan, M. Simulation of transboundary wastewater resource management scenarios in the Wadi Zomer watershed, using a WEAP model. Int. J. Basic Appl. Sci. 2015, 4(1), 27-35.

19. Shraideh, H.; Hasan, J.; Samhan, S. Water quality modeling of Zomar stream with considerations of current and future solutions. Proc. $7^{\text {th }}$ International Water Technology Conference. IWTC17, Istanbul, pp. 5-7, 2013.

20. Abu Ghosh, S.; Abu Jaffal, Y.; Homeidan, M.; Abu Salama, R.; Bitar, S. Wastewater Treatment Plant Nablus West Annual Report. Nablus Municipality, Nablus, Palestine, 2020.

21. Sulieman, S. Environmental Flow Regime for Wadi Zomar. M.Sc. Thesis, Faculty of Graduate Studies, Birzeit University, Birzeit, Palestine, 2010.

22. APHA (American Public Health Association). Standard Methods for the Examination of Water and Wastewater. 23th Ed., APHA-AWWA-WEF, Washington, DC, 2005.

23. Pansu, M.; Gautheyrou, J. Handbook of Soil Analysis: Mineralogical, Organic and Inorganic Methods. Springer-Verlag Berlin Heidelberg: Germany, 2006. pp. 581-91. 
24. Bello, A.O.; Tawabini, B.S.; Khalil, A.B.; Boland, C.R.; Saleh, T.A. Phytoremediation of cadmium-, lead- and nickel-contaminated water by Phragmites australis in hydroponic systems. Ecol. Eng. 2018, 120, 126-133.

25. Akan, J.C.; Abdulrahman, F.I.; Dimari, G.A.; Ogugbuaja, V.O. Physicochemical determination of pollutants in wastewater and vegetable samples along the Jakara wastewater channel in Kano Metropolis, Kano State, Nigeria. Eur. J. Sci. Res. 2008, 23(1), $122-133$.

26. Matamoros, V.; Rodríguez, Y. Influence of seasonality and vegetation on the attenuation of emerging contaminants in wastewater effluent-dominated streams. A preliminary study. Chemosphere, 2017, 186, 269-277.

27. Cañedo-Argüelles, M.; Kefford, B.J.; Piscart, C.; Prat, N.; Schäfer, R.B.; Schulz, C.-J. Salinisation of rivers: An urgent ecological issue. Environ. Pollut. 2013, 173, 157-167.

28. Mamba, B.B.; Krause, R.W.; Matsebula, B.; Haarhof, J. Monitoring natural organic matter and disinfection by-products at different stages in two South African water treatment plants. Water SA 2009, 35(1), 121-127

29. PSI, Palestinian Standards Institution. Technical Specification for Industrial Wastewater Discharge into Surface Water Bodies. PSI, Albireh, Palestine, 2010.

30. Dheri, G. S.; Brar, M.S.; Malhi, S.S. Heavy-metal concentration of sewage-contaminated water and its impact on underground water, soil, and crop plants in alluvial soils of northwestern India. Commun. Soil Sci. Plant Anal. 2007, 38(9-10), 1353-1370.

31. Qian, Y.; Zhang, W.; Yu, L.; Feng, H. Metal Pollution in Coastal Sediments. Current Pollution Reports, 2015, 1(4), 203-219.

32. Lu, X.; Zhang, Y.; Liu, H.; Xing, M.; Shao, X.; Zhao, F.; et al. Influence of early diagenesis on the vertical distribution of metal forms in sediments of Bohai Bay, China. Mar. Pollut. Bullet. 2014, 88(1-2), 155-161.

33. Khan, R.; Islam, M.S.; Tareq, A.R.; Naher, K.; Islam, A.R.; Habib, M.A.; et al. Distribution, sources and ecological risk of trace elements and polycyclic aromatic hydrocarbons in sediments from a polluted urban river in central Bangladesh. Environ. Nanotechnol. Monit. Manag. 2020, 14, 100318. 
34. Nemr, A.E.; Khaled, A.; Sikaily, A.E. Distribution and statistical analysis of leachable and total heavy metals in the sediments of the Suez Gulf. Environ. Monit. Assess. 2006, $118(1-$ 3), 89-112.

35. Milke, J; Gałczyn`ska, M.; Jacek Wróbel, J. The importance of biological and ecological properties of Phragmites Australis in Phytoremediation of aquatic ecosystems-The review. Water 2020, 12, 1770.

36. Shahid, M.J.; Ali, S.; Shabir, G.; Siddique, M.; Rizwan, M.; Seleiman, M.F.; Afzal, M. (2020). Comparing the performance of four macrophytes in bacterial assisted floating treatment wetlands for the removal of trace metals $(\mathrm{Fe}, \mathrm{Mn}, \mathrm{Ni}, \mathrm{Pb}$, and $\mathrm{Cr}$ ) from polluted river water. Chemosphere, 2020, 243, 125353.

37. Baldantoni, D.; Ligrone, R.; Alfani, A. Macro- and trace-element concentrations in leaves and roots of Phragmites australis in a volcanic lake in Southern Italy. J. Geochem. Explor. 2009, 101(2), 166-174.

38. Bragato, C.; Brix, H.; Malagoli, M. Accumulation of nutrients and heavy metals in Phragmites australis (Cav.) Trin. ex Steudel and Bolboschoenus maritimus (L.) Palla in a constructed wetland of the Venice lagoon watershed. Environmental Pollution, 2006, 144(3), 967-975.

39. Karami, N.; Clemente, R.; Moreno-Jiménez, E.; Lepp, N.W.; Beesley, L. Efficiency of green waste compost and biochar soil amendments for reducing lead and copper mobility and uptake to ryegrass. J. Hazard. Mater. 2011, 191(1-3), 41-48.

40. Stoltz, E.; Greger, M. Accumulation properties of $\mathrm{As}, \mathrm{Cd}, \mathrm{Cu}, \mathrm{Pb}$ and $\mathrm{Zn}$ by four wetland plant species growing on submerged mine tailings. Environ. Exp. Bot. 2002, 47(3), $271-$ 280 .

41. Sawidis, T.; Chettri, M.; Zachariadis, G.; Stratis, J. Heavy Metals in Aquatic Plants and Sediments from Water Systems in Macedonia, Greece. Ecotoxic. Environ. Saf. 1995, 32(1), 73-80.

42. Ji, Y.; Vollenweider, P.; Lenz, M.; Schulin, R.; Tandy, S. Can iron plaque affect Sb(III) and $\mathrm{Sb}(\mathrm{V})$ uptake by plants under hydroponic conditions. Environ. Exp. Bot. 2018, 148, 168-175. 
43. Windham, L.; Weis, J.; Weis, P. Uptake and distribution of metals in two dominant salt marsh macrophytes, Spartina alterniflora (cordgrass) and Phragmites australis (common reed). Estuar. Coast. Shelf S. 2003, 56(1), 63-72.

44. Chaney, R.L. Toxic Element Accumulation in Soils and Crops: Protecting Soil Fertility and Agricultural Food-Chains. In: Bar-Yosef B., Barrow N.J., Goldshmid J. (eds) Inorganic Contaminants in the Vadose Zone. Ecological Studies (Analysis and Synthesis), Vol 74. 1989, Springer, Berlin, Heidelberg.

45. Peverly, J.H.; Surface, J.M.; Wang, T. Growth and trace metal absorption by Phragmites australis in wetlands constructed for landfill leachate treatment. Ecol. Eng. 1995, 5(1), 21 35.

46. Fairbrother, A.; Wenstel, R.; Sappington, K.; Wood, W. Framework for Metals Risk Assessment. Ecotoxicol. Environ. Saf. 2007, 68, 145-227.

47. Yeh, T.; Chou, C.; Pan, C. Heavy metal removal within pilot-scale constructed wetlands receiving river water contaminated by confined swine operations. Desalination 2009, 249(1), 368-373.

48. Tam, N.; Wong, Y. Retention and distribution of heavy metals in mangrove soils receiving wastewater. Environ. Pollut. 1996, 94(3), 283-291.

49. Carranza-Álvarez, C.; Alonso-Castro, A.J.; Torre, M.C.; Cruz, R.F. Accumulation and Distribution of Heavy Metals in Scirpus americanus and Typha latifolia from an Artificial Lagoon in San Luis Potosí, México. Water, Air, Soil Pollut. 2007, 188(1-4), 297-309.

50. Phillips, D.; Human, L.; Adams, J. Wetland plants as indicators of heavy metal contamination. Mar. Pollut. Bull. 2015, 92(1-2), 227-232.

51. Keller, B.E.; Lajtha, K.; Cristofor, S. Trace metal concentrations in the sediments and plants of the Danube Delta, Romania. Wetlands 1998, 18(1), 42-50.

52. Samecka-Cymerman, A.; Stepien, D.; Kempers, A.J. Efficiency in removing pollutants by constructed wetland purification systems in Poland. J. Toxicol. Environ. Health, Part A, 2004, 67(4), 265-275.

53. Laing, G.D.; Moortel, A.V.; Moors, W.; Grauwe, P.D.; Meers, E.; Tack, F.; Verloo, M. Factors affecting metal concentrations in reed plants (Phragmites australis) of intertidal marshes in the Scheldt estuary. Ecol. Eng. 2009, 35(2), 310-318. 
54. Lesage, E.; Rousseau, D.; Meers, E.; Tack, F.; Pauw, N.D. Accumulation of metals in a horizontal subsurface flow constructed wetland treating domestic wastewater in Flanders, Belgium. Sci. Total Environ. 2007, 380(1-3), 102-115.

55. Allen, S.E. Chemical Analysis of Ecological Materials. $2^{\text {nd }}$ Ed. Blackwell: Oxford, UK. 1989; 368 pp. ISBN-10: 0632017422.

56. Vymazal, J.; Březinová, T. Heavy metals in plants in constructed and natural wetlands: Concentration, accumulation and seasonality. Water Sci. Technol. 2015, 71(2), 268-276.

57. Bermejo, J.S.; Beltrán, R.; Ariza, J.G. Spatial variations of heavy metals contamination in sediments from Odiel river (Southwest Spain). Environ. Int. 2003, 29(1), 69-77.

58. Feng, H.; Jiang, H.; Gao, W.; Weinstein, M.P.; Zhang, Q.; Zhang, W. Metal contamination in sediments of the western Bohai Bay and adjacent estuaries, China. J. Environ. Manag, 2011, 92(4), 1185-1197. 